\title{
Character Education in the New Paradigm of Pancasila Citizenship Education
}

\author{
Mahmuda Ma'arif ${ }^{1, *}$, Zalik Nuryana $^{2}$, Intisar Ambu Saidi $^{3}$ \\ ${ }^{1}$ Faculty of Social Science, Universitas Negeri Yogyakarta, Indonesia \\ ${ }^{2}$ Department of Islamic Education, Universitas Ahmad Dahlan Yogyakarta, Indonesia \\ ${ }^{3}$ Ministry of Education, Oman
}

Received August 18, 2020; Revised October 22, 2020; Accepted November 1, 2020

\section{Cite This Paper in the following Citation Styles}

(a): [1] Mahmuda Ma'arif, Zalik Nuryana, Intisar Ambu Saidi, "Character Education in the New Paradigm of Pancasila Citizenship Education," Universal Journal of Educational Research, Vol. 8, No. 12, pp. 6893 - 6901, 2020. DOI: 10.13189/ujer.2020.081255.

(b): Mahmuda Ma'arif, Zalik Nuryana, Intisar Ambu Saidi (2020). Character Education in the New Paradigm of Pancasila Citizenship Education. Universal Journal of Educational Research, 8(12), 6893 - 6901. DOI: 10.13189/ujer.2020.081255.

Copyright $\bigcirc 2020$ by authors, all rights reserved. Authors agree that this article remains permanently open access under the terms of the Creative Commons Attribution License 4.0 International License

\begin{abstract}
Countries recognize that character and citizenship education are vital factors in developing the most significant human resources. There are many challenges both to policies and to the implementation of character education and citizenship in schools. This study aims to investigate students' character development in terms of values and moral education by analyzing the 2013 curriculum of Indonesian citizenship education. The citizenship education curriculum has introduced new terms such as civics, state citizenship education, Pancasila moral education, Pancasila education and citizenship education, civic education, and Pancasila education and citizenship. This study looked at and critically analyzed the relevant literature on Indonesia's citizenship education. It is concluded that Citizenship Education aims at developing civilizations in Indonesia, in particular, the building of a nation's character, by achieving diverse objectives in order to attain the national goals. Therefore, citizenship education is undeniable learning that must be taught at all levels of education, whether at elementary, secondary or tertiary level. In addition, Citizenship Education plays a significant role through curricular programs in both formal and non-formal education institutions. Citizenship Education as a socio-cultural movement, acts as a vehicle for citizens' self-actualization, both individually and in groups, by emphasizing rights, obligations, and the socio-cultural context, through direct and responsible
\end{abstract}

active participation.

Keywords Character Education, Old Paradigm, New Paradigm, Citizenship Education, Education in Indonesia

\section{Introduction}

Character education is an increasing discipline in which the student's ethical conduct is deliberately optimized. The outcome of the education of character has always helped tomorrow's leaders with strength and continued preparation. Fostering character education should not only be a leap service but also should include a practical action plan [1]. Embedding character is fundamentally relational in virtue ethics, and the philosophy of treatment is more conditional than character education [2]. The success of character education is influenced by eight aspects, as explained in fig 1. The integration between aspects will affect the implementation of character education in schools. All aspects must be fulfilled for character education to be successful [3]. Citizenship education in Indonesia is called PPKn. PPKn is a science field used in Indonesia as a vehicle for developing and preserving a noble moral value rooted in the Indonesian nation with the hope that it can be manifested in the form of behavior in community members and God's creatures. 


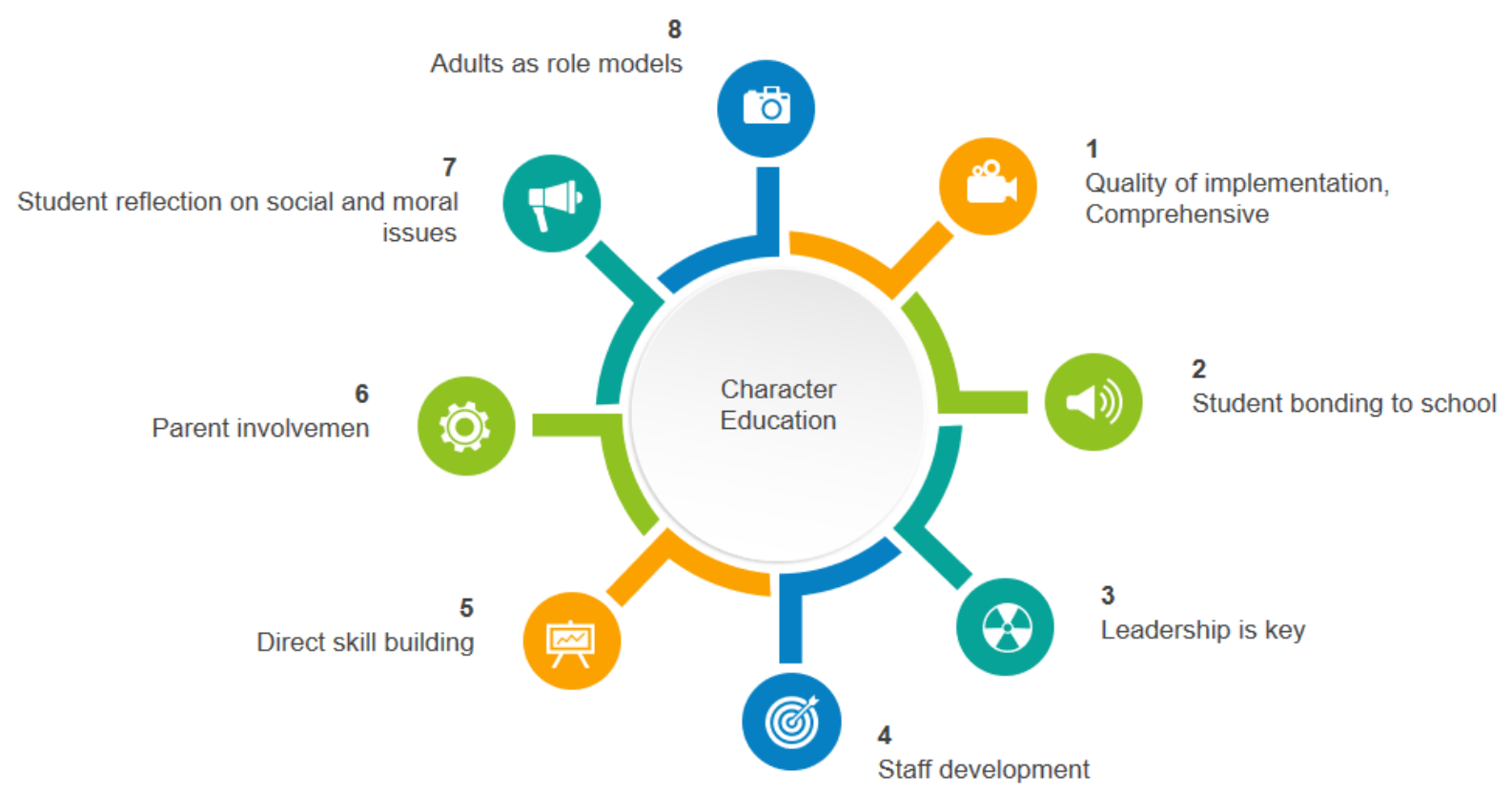

Figure 1. The key to a successful implementation of character education in schools

Effectual character education should include efforts to assess the impact of the program. At least three things can be seen in the exercise of character education: (1) the character of the classroom, (2) the development of the teaching staff, and (3) the character of the students [4]. Character education is an integral part of education in Indonesia and is embedded in all courses. However, religious education and citizenship education (PPKn) is the foundation for developing Indonesian students' character. PPKn aims to produce Indonesian people who have faith and are dedicated to God, with behavior and attitudes, to take responsible positions following their sense of morality. Education hence is not only in the things we can see, such as funding, accreditation, teachers, and policy [5], it also involves the implementing and inculcation of character education and citizenship.

Pancasila is the ideological pillar of the Indonesian state. This name consists of two words from Sanskrit: panca means five, and sila means principle. Pancasila is a formulation and guideline for the life of the nation and state for all Indonesian people. The lack of education in the context of the development of character education is inseparable from the failure of subject areas to integrate Pancasila's internalization in various fields, particularly the starting to learn of Pancasila education as well as the emphasis on citizenship. PPKn is one of the sciences that can shape the development of one's values, morality, and behavioral attitudes [6].

PPKn is also essential for citizens to carry out social life based on values that some people still underestimate. Practice education should strengthen aspects of character that contain amounts of goods that give rise to the attitudes or behavior of someone contrary to what is taught. Pancasila's education and citizenship are essential things in education to foster the ideology of Pancasila. Ideology is fundamental to play a role in uniting the Indonesian nation. Still, it can be considered in formulating or practicing it because it can be expressed or practiced contrary to Pancasila education and citizenship. Pancasila is also used as an instrument of indoctrination from the government to the younger generation through Pancasila Education and Citizenship, which fails because it contradicts the spirit of education [7].

For example, civics learning in America focuses more on training students' minds by memorizing (rote memory/memorization), directing and regularly advising with good material, where this method is more directed at teaching civics, which is indoctrinated or parrot-like instructions. As a country that pioneered the development of the concept and paradigm of citizenship education for the first time in the mid-1880s, it began introducing civics as subjects in schools that contained government material. In the 1900s, civics were developed, which contained material on state and federal government structures [8].

The socialization of its citizens must be a matter for every democratic society. It begins in childhood, and schools are crucial to this process. The relationship between character education (character education, moral education) and citizenship education (active citizenship, civic education) should not be separated, neither of which should be continued to pursue together because they are the foundation for the future formation of the student character [9]. Character education is a particular approach to education in morals or values, frequently related to citizenship [10].

The need to improve curriculum to achieve success in education is a public obligation. As an educator, the teacher's role is not just to transfer knowledge, but also 
he/she must be a person who exemplifies and guides his/her students to apply values in Pancasila, such as the value of honesty, fairness, and respect for others. Therefore, the importance of education in shaping cognitive, emotional, and psychomotor aspects in a balanced and sustainable manner. The educational journey in Indonesia has undergone a process of travel from using the SBC curriculum to currently using the 2013 curriculum, which is expected to bring about better changes in the Indonesian people's education. Besides, curriculum changes are expected to face challenges in the global era that continue to multiply in line with the times but do not fade national values.

Curriculum changes also affect the cognitive paradigm that is both cognitive and constructive, which impacts the teaching and learning process in schools. A new model that no longer focuses on students as the object of learning, but rather the student acts as the subject of the learning process in a class guided by a teacher as a student facilitator. In this case, students must be active in the classroom learning process, not to be an authoritative teacher in the classroom. The teacher acts as a facilitator and provides students with more opportunities to learn and grow according to their needs, interests, and talent while taking into consideration that learning remains conducive to the plans that have been prepared in the curriculum. According to Suminah, the curriculum is a guide for educators to facilitate quality education programs that support educational objectives [11].

Citizenship education is developing in terms of concepts, as has happened in Taiwan. According to Meihui, citizenship education is the subject of debate between individuals and society, freedom and order, diversity and uniformity, rights and responsibilities, deliberation on the virtues of citizenship, citizenship in general, and different citizenship [12]. Some of the community values were carried out by this community, such as obedience, filial piety, responsibility, and harmonization, embedded in teaching [13] and [15]. That is why this society upholds and respects traditional and modern traditions that may not be relevant. In writing this article, the authors explore commonly understood concepts related to the elements of character education, the old paradigm, and the new paradigm of citizenship education.

This paper sheds light on the citizenship education components. It explains the old and new paradigm concepts of citizenship education and character education that have not yet been debated by previous studies. This paper's key focus is on the international perspective on education policy and character education development in Indonesia through citizenship education. This study aims to analyze students' character development in values and moral education through the 2013 curriculum in Indonesian citizenship education. This research is essential because, by looking at the history of citizenship education development, we can optimize civic education as an urgent subject in Indonesia.
The new paradigm is the adjustment of the curriculum to the national education policy in Indonesia. The curriculum changes that occur aim to maximize civic education (PPKN) in the context of realizing citizenship education in Indonesia. Changes in content in PPKN subjects can be seen in table 1 . The changes include the name of subjects, lesson hours, learning focus, and PPKN objectives. For example, in 1962, with the name Pendidikan Kewarganegaraan (civic), with 2 hours of lessons, and aimed to understand citizenship for the community. Changed until 2013 under the name PPKN, It is now 3 hours to become a topic of particular interest than other topics, as PPKN is a central lesson in children's moral behavior education. Students should focus more on Pancasila's education, values, and behavior. PPKn learning should improve to encourage students to learn character values in line with Pancasila's values while considering the creation of juvenile delinquency. Civic teachers have more time to teach students this 13th hour, with three hours of planned curriculum instruction.

By knowing the process of adjusting to the goals of education in Indonesia from time to time, it is hoped that PPKN will be at the forefront of instilling civic values through education. Besides, character education in Indonesia is integrated with other subjects so that the optimization of PPKN goals in national education objectives can take place well.

\section{Discussion}

\section{Character Education in Indonesia}

Citizenship Education is a vehicle for character education designed to foster and develop smart and good citizens along the path of formal, informal, and non-formal education that has become part of national education goals in Indonesia [16]. Citizenship Education has a crucial role in developing attitudes, attitudes and behavior in harmony, peace, and tolerance, without leaving behind the diversity that has become the Indonesian nation [17]-[19]. The development of mind, attitudes, and behavior in harmony, peace, and tolerance will be the antithesis of all forms of conflict and violence.

Furthermore, the orientation towards developmental systems expands our perspective of character and character education. For example, there is a tendency to consider character education as a formal curriculum in schools. However, in early childhood, the fundamental principles of evolving morals and conscience are evident, and the dynamic of development and socialization in early family life is a type of education that will be interesting for researchers in the future. [20].

Davis describes

hree types of "character education": (1) simple moral education (basically, Kohlberg's moral education in the classroom), (2) fair community education (Deweyesque 
practice that emphasizes democratic decision-making outside the school), and (3) simple character education (trying to build character both inside and outside the nature of first class at the time) [21].

Citizenship Education in the development of civilizations in Indonesia, in particular, the building of a nation's character, has diverse objectives for the achievement of national goals, so that citizenship education is undeniable learning that must be taught at all levels of education, whether at elementary, secondary or tertiary level. Ubedillah and Rozak [22] explained that citizenship education as a vehicle for the development of national character has the following objectives: 1) Establishing quality and responsible citizen participation skills in the life of the nation and the state making Indonesian citizens smart, active, critical and democratic, yet committed to maintaining national unity and integrity. 2) Developing a civilized democracy culture, namely freedom, equality, tolerance, and responsibility [23].

Citizenship Education, the development of good citizens, has three competencies: citizenship, citizenship, and citizenship. The main requirements for a good citizen must have Pancasila-based knowledge, skills, and character. The assessment of one's behavior can be seen from the value of one's personality in everyday life. Salim explained that character could be defined as the values of virtue, morality, and morality embodied in human values that underlie human thoughts, attitudes, and behavior [24]. Generally, it can be said that the character is almost the same as the behavior. The character of a person can be seen from the point of birth. The development of age can also change the character of every human being. Character education is an effort to teach the fundamental values and moral habits of elementary and middle school students because early childhood character-setting can be embedded in the ethical rationale of fundamental values. Character education underlines the importance of three essential components of good character: moral knowledge, moral feeling, and moral action. [25].

Character-related learning according to Kirschenbaum is teaching character education by providing a direct application to what we do or show what we teach in reality so, it is easy for students to remember and will have an impact on them [26]. Values education must, therefore, be sustainable to be more productive. According to the Director-General for Secondary Development of the Ministry of National Education, the value of character education can be grouped into several groups in the existing fields of science, namely: spiritual and emotional development, intellectual development, physical and kinesthetic development, and the development of emotion and creativity. Whereas according to Lickona, there are ten virtues which can be used as the basis for shaping a person's character, namely: (1) wisdom; (2) justice; (3) courage; (4) self-control; (5) love; (6) positive attitude; (7) hard work and resourcefulness; (8) integrity; (9) gratitude;
(10) humility [27].Citizenship Education of the Old and the New Paradigm

In 1975, the term National Citizenship Education was changed to Pancasila Moral Education (PMP), which contained Pancasila material as outlined in the Pancasila Observing and Practicing Guidelines or P4. This change is consistent with the educational mission mandated by Tap. MPR II / MPR/1973 on the Guidelines for the Implementation and Implementation of Pancasila. Also, Pancasila Moral Education subjects are compulsory subjects for elementary, junior, high school, GSP, and vocational schools. This subject's scope includes citizens, Indonesian history, the 1945 Constitution, Pancasila, important development messages (such as the five-year development plan and the State Policy Outline) for the Indonesian people, specific state doctrines, and moral issues [28].

The development of the curriculum in 1984 led the government to enact Law No. 2 of 1989 on the National Education System. Article 39 of the Law sets out Pancasila Education and Citizenship Education as a compulsory curriculum study material for all pathways, types, and education levels. Pancasila Moral Education subjects, 1994 Primary and Secondary Education Curriculum, accepted the new educational mission by introducing Pancasila and Citizenship Education topics or PPKn. The scope of the material in the debate on Pancasila Moral Education includes human rights, principles and the meaning of justice, the Constitution of 1945, state institutions, the judiciary, Indonesian independence, international cooperation, and the study of Pancasila [28], [29].

PPKn curriculum in 1994 Organizing material is not based on the formulation of the values of the Pancasila Living and Practicing Guidelines (P4) but based on the concept of values taken from the core of the $\mathrm{P} 4$ and other official sources organized by the spiral of the conceptual approach to development [30]. This approach articulates the Pancasila precepts with their values for each level of education, class, and quarterly chess in each category. So that the discussion material in this PPKn has the first scope, values, morals, and norms and behavior that are expected to manifest in the life of society, nation, and the state as set out in P4. Second, the life of the political, economic, social, cultural, defense, and security ideology and the development of science and technology in the unity of the United States of the Republic of Indonesia are based on Pancasila and the Constitution of 1945. However, the most important thing is that civics education must be developed and deserve to improve Civics studies' other aspects or fields. This starts with citizens in the form not only of their knowledge to be aware of their rights and obligations as citizens, but also that they are given the ability to manage their economy for the welfare of individual citizens and can also help the country's economy, and they are given the skills to be able to creat quality and competitive products, besides that citizens are prepared to compete in the era of globalization. 


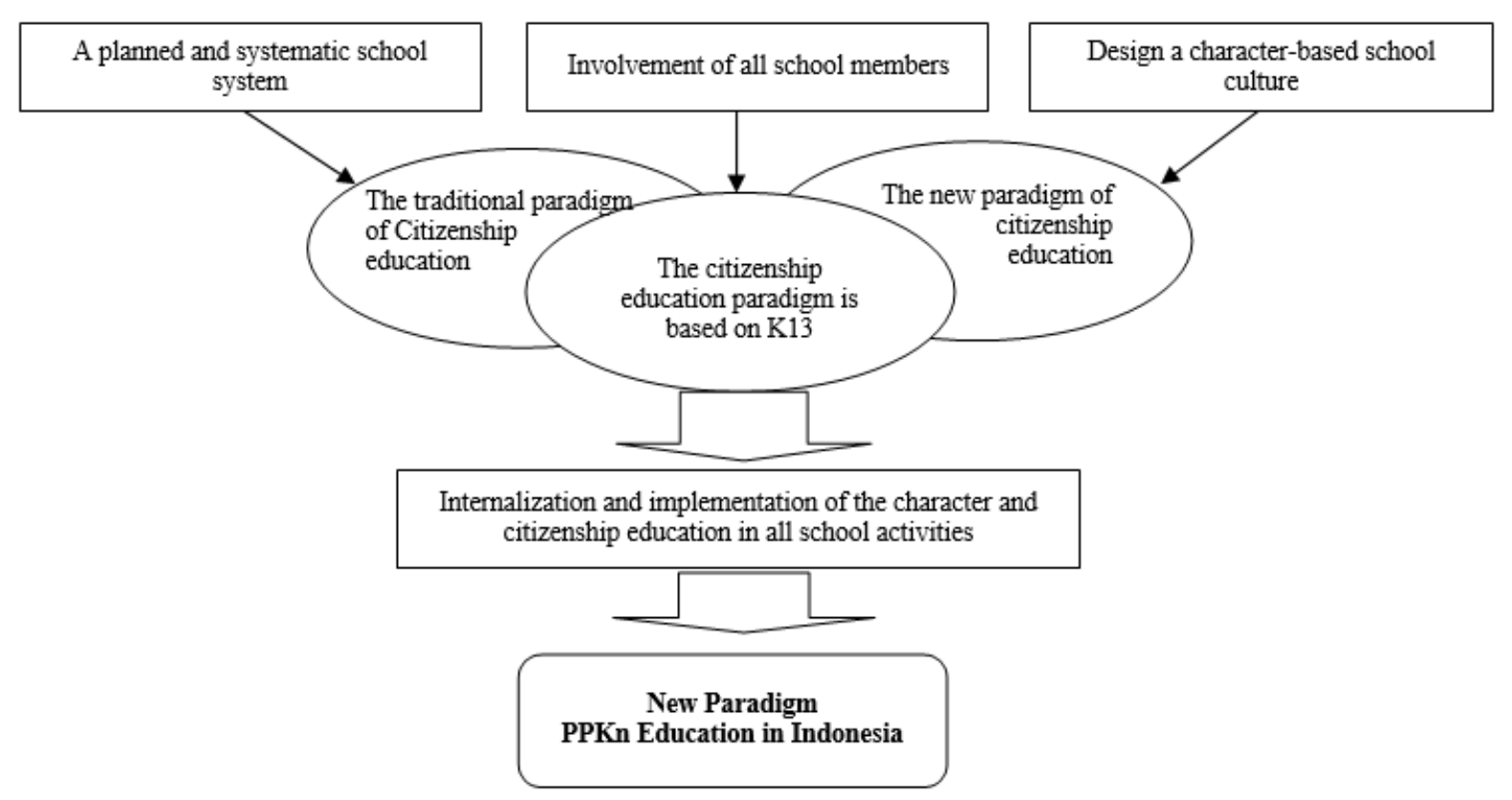

Figure 2. The concept of integration of old and new paradigms of citizenship education in Indonesia based on holistic policy

The 1994 curriculum has encourage students more to master knowledge materials. Knowledge material is provided to students following predetermined objectives. Based on Government Regulation No. 25 of 2000, the government, through the Ministry of National Education, has compiled national standards for all subjects in Indonesia, while the components organized by the government are (1) competency standards, (2) essential competencies, (3) subject matter and (4) achievement indicators. With the issuance of the Government Regulation, there was a change of name and curriculum as well as subjects that were initially Pancasila and Citizenship Education (PPKn ) for Citizenship Education (PKn) with a Competence-Based Curriculum or better known as KBK in 2004. The discussion material was in the eyes. This Citizenship Education lesson has scope for the unity of nation and state, values, and norms (religion, decency, courtesy, and law).

The process of developing a Competency-Based Curriculum is based on the assumption that students who will learn already have the fundamental knowledge and skills needed to master specific competencies. Therefore, the development of the 2004 curriculum pays attention to the principle of orientation towards the achievement of outcomes and their impact (outcome-oriented), based on standards of competence and core competencies, paying attention to the laws of differentiated curriculum development, developing aspects of learning in their entirety and in a holistic (holistic) way and applying the principle of mastery learning [31]. In the 2006 curriculum the subject of Civics Education (PKn) aims to have students have the ability; (1) think critically, rationally and creatively in responding to the issue of citizenship, (2) actively and responsibly participate, act intelligently in community, national and state activities, and anti-corruption, (3) develop positively and democratically to form themselves based on the characteristics of Indonesian society so that they can live together with other nations, (4) interacting with other countries in the world directly or indirectly by utilizing information and communication technology. This paper is offering a new concept of integration of old and new paradigm of citizenship education as shown in Fig 2. It shows the implementation of policies and the application of holistic character and citizenship education in Indonesia.

While the 2013 curriculum is the most recent curriculum used in Indonesia's education system, this curriculum is different from the previous curriculla, namely the Competency-Based Curriculum (KBK) and the Education Unit Level Curriculum (KTSP) in the aspects explained above. Changes to the concept in the 2013 Curriculum system include changes to the Graduation Competency Standards (SKL), changes in the curriculum structure, the achievement of student competencies tailored to the needs of the 21st century, and changes in learning based on a scientific approach [32]. Legally, the 2013 curriculum is based on National Education System Law No. 20 of 2003. Still, in its implementation, it is based on Government Regulation No. 32 of 2013 amending Government Regulation No. 19 of 2005 on National Education Standards. Curriculum changes also impact the subject of Civic Education in Indonesia, which initially used the term Civic Education or, better known as Civic Education, changed back to Pancasila and Citizenship Education or better known as PPKn. A comparison of the position of PPKn in the Indonesian curriculum can be found in Table 1. Several additions and deductions have been identified for each curriculum implementation period in Indonesia, both 
in terms of hours of learning and objective content.

Citizenship Education, which was later developed, is known as the new paradigm of Citizenship Education, which is very different from the old paradigm of Citizenship Education. Citizenship Education New paradigm experiences change in terms of material, strategy, and performance. In the old paradigm, Citizenship Education manifests itself as the indoctrination of the authorities' interests and nomologically moral standards that are useful in the design of holistic learning [33].

The essential factor that distinguishes between the old Citizen Education paradigm and the new paradigm is the effort to bring Citizen Education back into the path of science as an open field of study, a subject of learning and education, and a field of science that is independent of the pressures and interests of the ruling government. Citizenship Education The new paradigm, through civic knowledge, civic values, and civic skills, plays a role in addressing issues that arise in various sectors of the Indonesian nation's life.

Teachers must also play a role in instilling character in the implementation of learning because, in reality, there are teachers who do not care about it [34]. School teachers behave more positively concerning certain facets of character education and have a stronger sense of the success of character education for teachers who have graduated from private and religiously affiliated universities [35]. While education of character is seen as part of citizenship education in England's school curriculum, the data show that education does not form part of the educational curriculum [36]. This is the same as the condition in Indonesia that education is an integral part of citizenship education. To encourage the growth of character in our children, early childhood educators have some crucial roles. Early childhood teachers can positively impact young children's healthy development: induction, nutrition, demand, modeling, democracy, children's understanding, human values, caring relationships, emotional management, and expectations for children's teachers [37].

The development of PPKn in Indonesia has a long history of preparing good citizens following their rights and obligations. Civics have also undergone a lot of names and curriculum changes. They are starting with using the term civics, state citizenship education, Pancasila moral education, Pancasila education and citizenship education, civic education, and Pancasila education and citizenship. The United States Center for Civic Education has introduced the Citizenship Education model, which explains the systematic component of Citizenship Education. This model proposes three interrelated components, namely civic virtues, civic knowledge, and civic competence. Citizenship Education, which was subsequently developed in Indonesia, is known as the new paradigm of Citizenship Education. Citizenship education, which is a substantial distinction from the old paradigm of citizenship education, is positioned as a solution to the problems that arise in different life sectors through citizenship knowledge, citizenship values, and citizenship skills. 
Table 1. Comparison and development of PPKn curriculum in Indonesia

\begin{tabular}{|c|c|c|c|c|c|}
\hline Curriculum & $\begin{array}{l}\text { Name of } \\
\text { subjects }\end{array}$ & $\begin{array}{c}\text { Numbers } \\
\text { of hours }\end{array}$ & Learning focus & Learning goals & Explanation \\
\hline K 13 & PPKN & 3 hours & $\begin{array}{l}\text { The main focus is on } \\
\text { understanding the } \\
\text { content of } \\
\text { Pancasila 's } \\
\text { meaning, which is } \\
\text { linked to citizenship } \\
\text { education. }\end{array}$ & $\begin{array}{l}\text { Students can } \\
\text { understand and } \\
\text { practice } \\
\text { Pancasila and } \\
\text { statehood. }\end{array}$ & $\begin{array}{l}\text { This curriculum differs from the previous } \\
\text { curriculum, which was only } 2 \text { hours of learning and } \\
\text { suffered the loss of Pancasila values in the last } \\
\text { curriculum. Still, it is now } 3 \text { hours so that it becomes } \\
\text { a subject which is of particular importance } \\
\text { compared with other issues as PPKN is a crucial } \\
\text { lesson in the moral behavior education of children. } \\
\text { Students are supposed to concentrate more on the } \\
\text { schooling, morals, and actions of Pancasila. PPKn } \\
\text { learning should change and enable students to teach } \\
\text { character values in accordance with Pancasila 's } \\
\text { values when considering juvenile delinquency } \\
\text { development. At this 13th hour with three hours of } \\
\text { scheduled curriculum instruction, civic teachers } \\
\text { have more time for teaching students. }\end{array}$ \\
\hline KBK & $\mathrm{PKN}$ & 2 hours & $\begin{array}{l}\text { The main focus is } \\
\text { citizenship } \\
\text { education }\end{array}$ & $\begin{array}{l}\text { Civil education } \\
\text { students can } \\
\text { understand and } \\
\text { practice }\end{array}$ & $\begin{array}{l}\text { This program is substantially similar to KTSP. } \\
\text { Nevertheless, PKN wasn't especially interested } \\
\text { during KBK and KTSP. They were more neglected, } \\
\text { left behind, and felt that the lessons were less critical } \\
\text { to the national examination than the topics. }\end{array}$ \\
\hline KTSP & $\mathrm{PKN}$ & 2 hours & $\begin{array}{l}\text { The main focus is } \\
\text { citizenship } \\
\text { education }\end{array}$ & $\begin{array}{l}\text { Students can } \\
\text { understand and } \\
\text { practice } \\
\text { Citizenship } \\
\text { education }\end{array}$ & $\begin{array}{l}\text { Citizenship education is deemed satisfactory for } \\
\text { morality and success in the KTSP program with } 2 \\
\text { hours of instruction. The Pancasila word title is } \\
\text { omitted, however. The name Pancasila is eliminated } \\
\text { because the value of membership is indirectly } \\
\text { contained in citizenship education. }\end{array}$ \\
\hline 1994 & PPKN & 2 hours & $\begin{array}{l}\text { Focusing on } \\
\text { understanding the } \\
\text { content and meaning } \\
\text { of strengthening } \\
\text { Pancasila and } \\
\text { citizenship }\end{array}$ & $\begin{array}{l}\text { Students can } \\
\text { understand and } \\
\text { practice } \\
\text { Citizenship } \\
\text { education }\end{array}$ & $\begin{array}{l}\text { In this textbook, you will learn the content of the } \\
\text { title, plus the word Pancasila from the previous } \\
\text { curriculum that is used by the name moral in the } \\
\text { title. It is planned that this program will include } \\
\text { moral education plus civil and Pancasila education. }\end{array}$ \\
\hline 1975 & PMP & 2 hours & $\begin{array}{l}\text { Education that } \\
\text { focuses on moral } \\
\text { education based on } \\
\text { Pancasila }\end{array}$ & $\begin{array}{l}\text { Pancasila helps } \\
\text { students to } \\
\text { understand and } \\
\text { observe values }\end{array}$ & $\begin{array}{l}\text { It is specific in this program, which historically } \\
\text { focused on state education. PMP is supposed to } \\
\text { include not only the citizenship of the country as in } \\
\text { the last resume but also more material in moral } \\
\text { education and the actions and basic human lifestyles } \\
\text { that adhere to the Pancasila. }\end{array}$ \\
\hline 1968 & $\mathrm{PKN}$ & 2 hours & $\begin{array}{l}\text { Focusing on } \\
\text { understanding } \\
\text { citizenship }\end{array}$ & $\begin{array}{c}\text { Students are } \\
\text { better able to } \\
\text { understand and } \\
\text { practice } \\
\text { citizenship } \\
\text { education }\end{array}$ & $\begin{array}{l}\text { The word civics is modified in this curriculum to } \\
\text { PKN to give Indonesian a definite meaning to the } \\
\text { word civics. Complete the education that teaches } \\
\text { citizenship with the same lessons as before. }\end{array}$ \\
\hline 1962 & Civics & 2 hours & $\begin{array}{l}\text { Focusing on } \\
\text { understanding } \\
\text { citizenship }\end{array}$ & $\begin{array}{l}\text { Students can } \\
\text { understand and } \\
\text { practice } \\
\text { Citizenship } \\
\text { education } \\
\end{array}$ & $\begin{array}{l}\text { In stock for other nations, this program includes an } \\
\text { international word. However, the material is still } \\
\text { subject to Pancasila citizenship. }\end{array}$ \\
\hline
\end{tabular}




\section{Conclusions}

Citizenship Education in the development of civilizations in Indonesia, in particular, the building of a nation's character, has diverse objectives for the achievement of national goals, so that citizenship education is undeniable learning that must be taught at all levels of education, whether at elementary, secondary or tertiary level. Citizenship Education plays a significant role through curricular programs in both formal and non-formal education institutions. Citizenship Education as a socio-cultural citizenship movement, acting as a vehicle for citizens' self-actualization, both individually and in groups, by rights, obligations, and the socio-cultural context, through direct and responsible active participation.

\section{Acknowledgments}

We are very grateful to experts for their appropriate and constructive suggestions to improve this paper.

\section{REFERENCES}

[1] A. Agboola and K. C. Tsai, "Bring Character Education into Classroom.," Eur. J. Educ. Res., vol. 1, no. 2, pp. 163-170, 2012.

[2] N. Noddings, Educating moral people: A caring alternative to character education. ERIC, 2002.

[3] M. W. Berkowitz and M. C. Bier, "Research-Based Character Education," Ann. Am. Acad. Pol. Soc. Sci., vol. 591, no. 1, pp. 72-85, Jan. 2004.

[4] T. Lickona, "Eleven Principles of Effective Character Education," J. Moral Educ., vol. 25, no. 1, pp. 93-100, Mar. 1996.

[5] Z. Nuryana, I. Nurcahyati, A. Rahman, F. Setiawan, and D. Fadillah, "The Challenges and Solutions of Teachers' Problems to Achieve Education Golden Era," Universal Journal of Educational Research, vol. 8, no. 2, pp. 583-590, Feb. 2020.

[6] G. R. Pertiwi, H. Yanzi, and R. Rohman, "Peran Guru Dalam Meningkatkan Minat Peserta Didik SMK Terhadap Mata Pelajaran PPKn ," 2019.

[7] H. A. R. Tilaar, Kaleidoskop pendidikan nasional: Kumpulan karangan. Penerbit Buku Kompas, 2012.

[8] L. D. Zeleny and R. E. Gross, "Dyadic role-playing of controversial issues," Soc. Educ., vol. 24, pp. 354-358, 1960.

[9] W. Althof and M. W. Berkowitz*, "Moral education and character education: their relationship and roles in citizenship education," J. Moral Educ., vol. 35, no. 4, pp. 495-518, Dec. 2006.

[10] J. Arthur, "The Re-Emergence of Character Education In
British Education Policy," Br. J. Educ. Stud., vol. 53, no. 3, pp. 239-254, Sep. 2005.

[11] D. P. A. U. Dini and P. Masyarakat, "Kurikulum Pendidikan Anak Usia Dini Apa, Mengapa dan Bagaimana," Jakarta Direktorat Pembin. Pendidik. Anak Usia Dini, 2015.

[12] L. Meihui, "A Society in Transition: The Paradigm Shift of Civic Education in Taiwan," in Citizenship Education in Asia and the Pacific, 2004.

[13] W. O. Lee, "Tensions and Contentions in Citizenship Curriculum in Asia and the Pacific," in Citizenship Curriculum in Asia and the Pacific, 2008.

[14] Citizenship Curriculum in Asia and the Pacific. 2008.

[15] W. O. Lee, "The Development of Citizenship Education Curriculum in Hong Kong after 1997: Tensions between National Identity and Global Citizenship," in Citizenship Curriculum in Asia and the Pacific, 2008.

[16] P. Widiatmaka, "Kendala Pendidikan Kewarganegaraan dalam membangun karakter peserta didik di dalam proses pembelajaran," J. Civ. Media Kaji. Kewarganegaraan, 2016.

[17] P. Dianti, "Integrasi Pendidikan Karakter Dalam Pembelajaran Pendidikan Kewarganegaraan Untuk Mengembangkan Karakter Siswa," J. Pendidik. ILMU Sos., 2016.

[18] M. MURDIONO, "Pendidikan Anti Korupsi Terintegrasi dalam Pembelajaran PKn untuk Menanamkan Karakter Kejujuran di SMP,” SOCIA J. Ilmu-Ilmu Sos., 2016.

[19] M. I. Kurniawan, "Integrasi Pendidikan Karakter ke dalam Pembelajaran Kewarganegaraan di Sekolah Dasar," J. Pemikir. dan Pengemb. Sekol. Dasar, 2013.

[20] D. K. Lapsley and D. Narvaez, "Character Education," in Handbook of Child Psychology, Hoboken, NJ, USA: John Wiley \& Sons, Inc., 2007.

[21] M. Davis, "What's Wrong with Character Education?," Am. J. Educ., vol. 110, no. 1, pp. 32-57, Nov. 2003.

[22] A. Ubaedillah and A. Rozak, Pancasila, Demokrasi, HAM dan Masyarakat Madani. Prenadamedia, 2016.

[23] A. R. Nasution, "Urgensi Pendidikan Kewarganegaraan sebagai Pendidikan Karakter Bangsa Indonesia melalui Demokrasi, HAM dan Masyarakat Madani," JUPIIS J. Pendidik. ILMU-ILMU Sos., 2016.

[24] A. Salim, Manajemen Pendidikan Karakter di Madrasah (Sebuah Konsep dan Penerapannya). 2015.

[25] T. Lickona, Educating for character: How our schools can teach respect and responsibility. Bantam, 2009.

[26] H. Kirschenbaum, "From Values Clarification to Character Education: A Personal Journey," J. Humanist. Couns. Educ. Dev., 2000.

[27] M. Davidson, T. Lickona, and V. Khmelkov, "Smart \& good schools a new paradigm for high school character education," Handb. Moral Character Educ., pp. 290-307, 2014.

[28] G. dkk Santoso, "Analysis SWOT civic education curriculum for Senior High School year 1975-2013 pendidikan kewarganegaraan jenjang SMA," E J. Univ. 
Pendidik. Indones., 2015.

[29] S. Gunawan Santoso, "Analysis Swot Civic Education Curriculum for Senior High School Year 1975-2013," CIVICUS, 2015.

[30] P. Widiatmaka, "Kendala Pendidikan Kewarganegaraan dalam membangun karakter peserta didik di dalam proses pembelajaran," J. Civ. Media Kaji. Kewarganegaraan, vol. 13, no. 2, pp. 188-198, Dec. 2016.

[31] A. P. Wibowo and M. Wahono, "Pendidikan Kewarganegaraan: usaha konkret memperkuat multikulturalisme di Indonesia," J. Civ. Media Kaji. Kewarganegaraan, vol. 14, no. 2, pp. 196-205, Oct. 2017.

[32] Z. Nuryana, "Curriculum 2013 and The Future of Islamic Education In Indonesia.” 29-May-2019.

[33] S. Suharno, "Pengembangan aspek moral dalam Pendidikan
Kewarganegaraan SD dan SMP: Respons atas realitas keprihatinan moral," J. Civ. Media Kaji. Kewarganegaraan, vol. 13, no. 2, pp. 162-171, Dec. 2016.

[34] M. A. Mt and A. Mustaffa, "Teachers Perception in Inculcating Islamic Values in Secondary Schools," Int. J. Educ. Learn., vol. 1, no. 2, pp. 83-88, Dec. 2019.

[35] A. J. Milson and L. M. Mehlig, "Elementary School Teachers' Sense of Efficacy for Character Education," $J$. Educ. Res., vol. 96, no. 1, pp. 47-53, Sep. 2002.

[36] L. Revell and J. Arthur, "Character education in schools and the education of teachers," J. Moral Educ., vol. 36, no. 1, pp. 79-92, Mar. 2007.

[37] M. W. Berkowitz and J. H. Grych, "Early Character Development and Education," Early Educ. Dev., vol. 11, no. 1, pp. 55-72, Feb. 2000. 